\title{
REVIEW
}

\section{Joseph D. Small and Gilbert S. Rosenthal, eds. Let Us Reason Together: Christians and Jews in Conversation}

\author{
(Louisville: Witherspoon Press, 2010), paperback, xiv + 176 pp.
}

Alan L. Berger, Florida Atlantic University

This volume emerges from a series of four Jewish-Presbyterian consultations convened by the Presbyterian Church U.S.A. and the National Council of Synagogues between 2005 and 2009. The views of fifteen distinguished Jewish and Presbyterian thinkers are presented in four sections: "Probing the Relationship," "The Land," "Evangelism," and "Identity." It preserves the dialogic format of the consultations by pairing most of the presentations with responses from members of the other religious group. They focus on the key points raised in the 1987 document A Theological Understanding of the Relationship Between Christians and Jews (TURCJ), which was adopted by the Presbyterian Church as a pastoral and teaching document. Among the contributors are Joseph D. Small, Stephen R. Haynes, Anna Case-Winters, Leanne Van Dyke, and Rebecca Weaver (on the Presbyterian side), and David Berger, Reuven Hammer, and Steven M. Cohen (on the Jewish side). Their dialogue reveals both points of theological contact and areas of disagreement.

At the start they recognize that contemporary Christian-Jewish dialogue is fraught with mixed signals and a widespread lack of historical and theological awareness. One of the many asymmetries in the dialogue is that while Judaism does not require Christianity for its selfunderstanding, Christianity very much depends on "truthful theological and ecclesial understandings of the relationship between the two People of God" (p. x). The editors of this slim but valuable volume have produced an important study for those wishing to join the ongoing quest for a positive relationship between Christian and Jewish communities. This quest, Rosenthal and Small trenchantly observe, is "always fragile, especially when [it is] not accompanied by regular consultation and dialogue" (p. x).

The 1987 statement, included in the volume, consists essentially of three types of guidelines. Some of them are self-evident and non-controversial. For example, it says that contemporary theology is done in an expanding global and pluralistic milieu which is both interpersonal and inter-communal. Many guidelines have been well-received by Jews, such as the demand that dialogue be "entered into with a spirit of humility and a commitment to reconciliation" (p. 9), eschewing all proselytism, and reflect the insistence that "the Church's attitudes must be reviewed and changed as necessary so that they can never again fuel the fires of hatred" (p. 10). Other sections reveal a more critical view of Israel. For example, the statement contains a confession of "[Presbyterian] complicity in the loss of land by Palestinians," and a call to "join with those of our Jewish sisters and brothers who stand in solidarity with Palestinians as they cry for justice as the dispossessed" (p. 11).

Stephen Haynes' assessment of TURCJ is helpful. He makes several noteworthy points. Supersessionism, a commonplace of traditional Christian belief, remains a threat to Presbyterian- 
Jewish understanding. Reflecting on the document's assertion that both Jews and Presbyterians are elected by God, Haynes notes this is a "reminder for contemporary Presbyterians of an important theological truth-that election is about what God does, not about how we respond" ( $p$. 19). But, he notes, this claim stands in tension with the Church's views of evangelism. When discussing evangelism, the PCUSA claims that "Jesus Christ is the only Savior and Lord" and makes no "references to the unique relationship between Christians and Jews" (p. 20). Haynes also urges the Church to make a "stronger statement" concerning the evils of slavery and the Holocaust and to humbly apologize for the "results of bad theology and biblical interpretation" ( $p$. 21). The author also warns against the document's facile utilization of liberation theology and its undue influence on "Presbyterian views of Israel-Palestine" (p. 23).

The topic of the land is, as one might expect, the one that elicits the most passionate views. Reuven Hammer distinguishes Eretz Yisrael-the land of Israel-and Medinat Yisrae/-the State of Israel. The former is a theological category while the latter is a secular-political one. Despite this distinction, he notes that for contemporary Jews "the [S]tate has a status more important than a mere political entity" (p. 90). The land itself plays an irreducible role in the divine-human drama. It is the only place where the Jewish people can completely aspire to fulfill God's will, which in the end will result in "the establishment of the sovereignty of God on earth" (p. 93). It is, argues Hammer, "vital that Christians understand the centrality of the land to Jewish belief" ( $p$. 94).

Rebecca Weaver's thoughtful response to Reuven Hammer illustrates the tension between their views of Israel. She asks the question vital to any fruitful dialogue: "Why is it so difficult for those of us who are Christians to grasp your meaning?" (p. 98). Weaver asks Hammer's help in seeking to understand why the contemporary State of Israel is necessary for the "fulfillment of that obedience [to the commandments] or the accomplishment of the divine purpose." She admits that "we [Presbyterians] simply do not understand" this claim (pp. 98-99). Weaver attests that, because of the Christ-event, the land of ancient Israel is part of who Christians are as well. Yet she concludes her essay by observing a crucial difference between Jews and Christians, especially Presbyterians; for Jews the land of Israel represents not only memory but hope. Professor Weaver cogently calls for a joint exploration of this difference (p. 105).

The essays on identity written by Steven M. Cohen and Joseph S. Small reveal several commonalities between American Judaism and Presbyterianism, especially in the area of group identity. Cohen observes that, "In contrast with just fifty years ago, today's Jews have far fewer Jewish spouses, friends, neighbors and co-workers" (p. 147). Small notes that for Christians, "The Church is only one of a profusion of religious options ranging from enduring traditions such as Islam, Buddhism and Hinduism to New Age spiritualities. Americans see themselves as spiritual, but not religious" (p. 166). Both seem to agree that the world is simply too much with us. There is widespread acceptance of many truths as opposed to an absolute Truth in the realm of religion. Spiritual healing is as likely to come from yoga classes as it is from attending church or synagogue services. Consequently, Small refers to the "cultural disestablishment [of Christianity] and a pervasive pluralism...exacerbated by internal theological disarray" (p. 108). Cohen likewise points to the "many ways outside of religious congregational life in which American Jews are Jewishly engaged" (p.155).

This volume is a good primer of Presbyterian-Jewish relations. It is, however, flawed, in refraining from discussing - or even mentioning - the contentious and potentially destructive issue of the political battle against Israel being waged by certain groups in the Church. I refer to the socalled BDS (boycott, divestment, sanction) movement, which propounds a dualistic (i.e., antiIsrael, pro-Palestinian) reading of the Middle East conflict. This conflict is complex and requires 
great nuance and understanding. The BDS movement displays neither of these attributes. This matter illustrates that dialogue, if it is to be serious and meaningful, must deal with vital issues. The contributors to this volume reveal that such a dialogue can occur in a civilized, historically informed, and articulate manner. 